\title{
Socialna sprejetost nadarjenih učencev in učencev z dodatno strokovno pomočjo v osnovni šoli
}

\author{
Marina Horvat ${ }^{1 *}$ in Katja Košir ${ }^{2}$ \\ ${ }^{1}$ Maribor \\ ${ }^{2}$ Oddelek za temeljne pedagoške predmete, Pedagoška fakulteta, Univerza v Mariboru
}

\begin{abstract}
Povzetek: Raziskave vrstniških odnosov v šolskem okolju so običajno izvedene na normativnih vzorcih učencev, manj pa je znanega o podskupinah učencev, ki imajo določene posebnosti, zaradi katerih je tveganje za razvoj problemov z vrstniki v šoli in posledično za težave s kasnejšo prilagojenostjo večje. S tem namenom smo želeli preveriti, kako so socialno sprejeti nadarjeni učenci in učenci z dodatno strokovno pomočjo v 6. in 8. razredu osnovne šole. V raziskavi je bilo udeleženih 194 učencev (50,5\% deklet) iz 12 oddelkov osnovnih šol, od tega 16 učencev $(8,3 \%$ z dodatno strokovno pomočjo (DSP), 39 identificiranih nadarjenih učencev $(20,1 \%)$ in ena nadarjena učenka z DSP. Uporabljena je bila sociometrična preizkušnja s pozitivnim in z negativnim kriterijem. Največ učencev z DSP je bilo uvrščeno v skupino zavrnjenih in povprečnih učencev. Učenci z DSP so s strani svojih sošolcev prejeli najmanj pozitivnih in vzajemnih ter največ negativnih izbir. Razlike v socialni sprejetosti učencev z DSP glede na spol in starost niso bile statistično pomembne. Nadarjeni učenci so prejeli največ pozitivnih in vzajemnih ter najmanj negativnih izbir. Najpogosteje so bili uvrščeni v skupino povprečnih ali priljubljenih učencev, vendar v primerjavi z učenci brez DSP niso bili bolj socialno sprejeti; so pa bili bolj sprejeti v primerjavi z učenci z DSP. Ugotovitve raziskave kažejo na pomembnost raziskovanja podskupin učencev z DSP v prihodnjih raziskavah.
\end{abstract}

Ključne besede: socialna sprejetost, nadarjeni učenci, učenci z dodatno strokovno pomočjo, sociometrične skupine, sociometrija

\section{Social acceptance of gifted pupils and pupils with additional professional help in elementary school}

\author{
Marina Horvat ${ }^{1}$ and Katja Košir ${ }^{2}$ \\ ${ }^{1}$ Maribor, Slovenia \\ ${ }^{2}$ Department of Basic Pedagogical Studies, Faculty of Education, University of Maribor, Slovenia
}

\begin{abstract}
Studies of peer relations in school settings are typically conducted on normative samples of pupils. Less is known about subgroups of pupils with some exceptionalities who may be more vulnerable to developing peer problems in school and are subsequently at risk for later maladjustment. The purpose of present study was therefore to examine social acceptance of gifted pupils and pupils with additional professional help in 6th and 8th-grade of regular elementary school. 194 pupils (50.5\% girls) from 12 classes participated in the study; 16 of them (8.3\%) were pupils with additional professional help (APH), 39 gifted pupils (20.1\%) and one gifted pupil with APH. A composite positive and negative nomination sociometric procedure was employed. Most of the pupils with APH were in rejected and average sociometric group. Pupils with APH received the lowest number of positive and reciprocal nominations and the highest number of negative nominations. Compared to gifted pupils they were less accepted, although no difference in acceptance was found compared to the non-APH pupils. Results showed no significant differences in acceptance of pupils with APH in regard to grade level or gender. Gifted children received the highest number of positive and reciprocal and the lowest number of negative nominations. They were more likely to be average and popular, although no differences in acceptance was found compared to non-gifted pupils. Results suggest the importance of investigating subgroups of pupils with APH in future research.
\end{abstract}

Keywords: social acceptance, gifted students, students with additional professional help, sociometric groups, sociometry

"Naslov/Address: Marina Horvat, Smetanova ulica 57, 2000 Maribor, e-mail: marina.horvat@uni-mb.si

Članek je licenciran pod pogoji Creative Commons Attribution 4.0 International licence. (CC-BY licenca).

The article is licensed under a Creative Commons Attribution 4.0 International License (CC-BY license). 
Otroci s posebnimi potrebami so po zakonu o usmerjanju otrok s posebnimi potrebami (Ur. 1. RS št. 03/2007) otroci z motnjami v duševnem razvoju, slepi in slabovidni otroci, gluhi in naglušni otroci, otroci z govornojezikovnimi motnjami, gibalno ovirani otroci, dolgotrajno bolni otroci, otroci $\mathrm{s}$ primanjkljaji na posameznih področjih učenja ter otroci s čustvenimi in vedenjskimi motnjami, ki potrebujejo prilagojeno izvajanje programov vzgoje in izobraževanja $\mathrm{z}$ dodatno strokovno pomočjo ali prilagojene programe vzgoje in izobraževanja oziroma posebne programe vzgoje in izobraževanja. Velika večina teh otrok je vključena $\mathrm{v}$ program osnovne šole (predvsem učenci s primanjkljaji na posameznih področjih učenja in učenci $\mathrm{z}$ mejnimi intelektualnimi sposobnostmi), nekoliko manj jih je vključenih $\mathrm{v}$ osnovno šolo $\mathrm{s}$ prilagojenim programom (predvsem učenci z motnjami $\mathrm{v}$ duševnem razvoju), manj $\mathrm{v}$ druge posebne zavode ter nekaj v socialno varstvene zavode (Opara, 2005). Med vsemi slovenskimi osnovnošolci je v letu 2010 bil največji delež vključenih otrok s posebnimi potrebami (OPP) $\mathrm{v}$ program redne osnovne šole zaradi primanjkljajev na posameznih področjih učenja (3\%), sledijo OPP zaradi dolgotrajne bolezni (1\%) in govorno jezikovnih motenj (1 \%). Učenci s primanjkljaji na posameznih področjih učenja predstavljajo nekaj več kot $50 \%$ vseh usmerjenih učencev s posebnimi potrebami osnovnošolske starosti (Opara idr., 2010). Tem učencem (z odločbo o usmeritvi) je v programu osnovne šole nudena dodatna strokovna pomoč. V raziskavi zaradi načina ugotavljanja teh učencev uporabljamo izraz učenci $\mathrm{z}$ dodatno strokovno pomočjo (DSP).

Opredelitve nadarjenosti so $\mathrm{v}$ strokovni literaturi neenotne in definicija nadarjenosti predstavlja eno izmed najbolj perečih vprašanj na področju izobraževanja nadarjenih in talentiranih (Subotnik, Olszewski-Kubilius in Worrell, 2011), zato je tudi neposredna primerjava rezultatov različnih raziskav problematična. $\mathrm{V}$ eni izmed najpogosteje uporabljenih definicij nadarjenosti so kot nadarjeni opredeljeni tisti učenci, ki na predšolski, šolski ali srednješolski ravni izobraževanja kažejo visoke dosežke ali potenciale na intelektualnem, ustvarjalnem, specifično akademskem, vodstvenem ali umetniškem področju in kateri zaradi svojih specifičnih potreb poleg rednega izobraževalnega programa potrebujejo posebej prilagojene programe in aktivnosti (Travers, Elliott in Kratochwill, 1993). V Sloveniji se pri delu z nadarjenimi učenci opiramo na Renzullijev model (1986), ki pri opredeljevanju nadarjenosti upošteva visoke sposobnosti, ustvarjalnost in predanost nalogi.

Obe omenjeni skupini učencev - tako tisti z DSP kot nadarjeni- lahkozaradisvojihznačilnostivpsihosocialnem delovanju predstavljata skupini $\mathrm{z}$ večjim tveganjem za razvoj težav v medosebnih odnosih. Raziskave s področja psihosocialnega funkcioniranja učencev $\mathrm{z}$ učnimi težavami so tako pokazale, da imajo ti učenci običajno več težav na številnih področjih socialne prilagojenosti v primerjavi z učenci, ki učnih težav nimajo. Tako imajo pogosteje težave s pozornostjo, dosegajo nižji učni uspeh ter imajo posledično tudi nižjo učno samopodobo in motivacijo za učenje, poleg tega pa so izpostavljeni višjemu tveganju za probleme s socialno integracijo (Gadeyne, Ghesquière in Onghena, 2004). Težave pri vstopanju v socialne interakcije opažajo že pri predšolskih otrocih s posebnimi potrebami. V primeru, da niso deležni ustrezne strokovne obravnave, težje razvijajo socialno kompetentnost $\mathrm{v}$ odnosu z vrstniki; obenem doživljajo manj pozitivnih odgovorov na svoje poskuse vključevanja v socialne interakcije, zato posledično lahko izražajo manj zanimanja za vrstnike, kar jih utegne voditi v še večjo socialno izolacijo (McConnell in Odom, 1999; v Kobal Grum idr., 2009). Wiener in Tardif (2004) sta empirično ugotovili, da imajo učenci z učnimi težavami tudi nižjo učno samopodobo ter manj razvite socialne spretnosti. Po drugi strani pa izsledki raziskav, ki primerjajo programe splošne osnovne šole in šole s prilagojenim programom pričajo o pomembnosti socialne integracije, saj se učenci s posebnimi potrebamiv programih splošnega izobraževanja počutijo manj stigmatizirane $\mathrm{v}$ primerjavi $\mathrm{z}$ otroci, ki so vključeni šole s prilagojenim programom, poleg tega pa so $\mathrm{v}$ programih splošnega izobraževanja skupaj z otroki brez primanjkljajev, ki jim služijo kot model primernega vedenja (Weiner in Tardif, 2004). Socialna integracija je povezana tudi $z$ ugodnimi učinki na učno uspešnost integriranih učencev (Guralnick, 1999). Pregled več raziskav Kalambouke, Farrella, Dysona in Kaplana (2007) na temo učnih dosežkov učencev s kognitivnimi in učnimi težavami, ki so vključeni v program osnovne šole kaže, da ima inkluzija običajno nevtralne učinke na učne dosežke, nekaj jih poroča o pozitivnih učinkih, medtem ko nobena izmed raziskav ni odkrila negativnega učinka na učne dosežke učencev s kognitivnimi in učnimi težavami. Učenci z učnimi težavami, ki so integrirani v program osnovne šole, so bolj priljubljeni in sprejeti in imajo bolj pozitivno samopodobo kot učenci z učnimi težavami, ki so vključeni v šole s prilagojenim programom (Gartner in Lipsky, 1987, v Wiener in Tardif, 2004). V šolah s prilagojenim programom imajo učenci $\mathrm{s}$ posebnimi potrebami sicer enako število prijateljstev kot otroci $\mathrm{s}$ podobnimi težavami, vključeni $\mathrm{v}$ program splošnega izobraževanja, poročajo pa o nižji kakovosti prijateljstev, izkušajo več osamljenosti in imajo več vedenjskih težav kot njihovi sovrstniki s podobnimi težavami, ki so vključeni v programe inkluzivnega izobraževanja (Wiener in Tardif, 2004). Isti avtorici zaključujeta, da so učenci, ki so vključeni $\mathrm{v}$ bolj inkluzivne programe, socialno in emocionalno bolje prilagojeni. Po drugi strani pa nekatere raziskave kažejo, da so učenci šol s prilagojenim programom $\mathrm{v}$ primerjavi $\mathrm{z}$ integriranimi učenci $\mathrm{v}$ programu redne osnovne šole bolje socialno in emocionalno integrirani, kar pripisujejo strnjeni, bolj homogeni skupini učencev, kjer svoje dosežke primerjajo le s sebi podobnimi, zato je njihova samoocena sposobnosti mnogo višja (Schmidt, 2001). Šole s prilagojenim programom tako pomembno oblikujejo pozitivno samopodobo učencev s posebnimi potrebami. 
Raziskave, ki so preučevale socialne odnose nadarjenih učencev kažejo, da se večina nadarjenih učencev dobro integrira $\mathrm{v}$ šolski sistem, medtem ko se manjšina nadarjenih učencev v pouk ne vključuje, ga moti, prekinja, postavlja vprašanja, ali pa so nasprotno povsem pasivni in odmaknjeni (Jeriček, 2003). V primerjavi z učenci, ki so učno zelo uspešni, niso pa identificirani kot nadarjeni, nadarjeni kažejo bolj pozitivno splošno samopodobo in samopodobo na področju medosebnih odnosov (Bain in Bell, 2004; Litster in Roberts, 2011). Tudi metaanaliza 40 raziskav s področja funkcioniranja nadarjenih učencev je pokazala, da slednji dosegajo statistično pomembno višje rezultate na merah zaznane učne kompetentnosti (Litster in Roberts, 2011). V nadaljevanju podrobneje predstavljamo izsledke raziskav, ki so preučevale socialno sprejetost učencev s posebnimi potrebami in nadarjenih učencev.

\section{Socialna sprejetost učencev $\mathbf{z}$ dodatno strokovno pomočjo}

Socialno sprejetost definiramo kot na odnose vezan konstrukt, ki nam daje informacijo o tem, kako je nek posameznik všeč oziroma ni všeč ostalim članom skupine in je za razliko od diadnih odnosov, kot je prijateljstvo, opredeljen na nivoju vrstniške skupine (Buhs in Ladd, 2001). Med odraščanjem in še posebej v času osnovne šole so zadovoljivi vrstniški odnosi zelo pomembni, saj otroke postavljajo pred nove zahteve, obenem pa jim nudijo nove priložnosti za socialni in emocionalni razvoj (GiffordSmith in Brownell, 2003). Nizka sprejetost s strani vrstnikov je povezana $\mathrm{z}$ vrsto negativnih razvojnih izidov, kot so delinkventnost, ponavljanje razreda, psihološka neprilagojenost, pa tudi nižji šolski uspeh, ki ga nekateri avtorji pripisujejo negativnim vrstniškim izkušnjam, kar je lahko povezano z nižjo motivacijo za šolsko delo in posledično s šolsko neuspešnostjo (Buhs in Ladd, 2001). Iz teh razlogov je preučevanje socialne sprejetosti pri ranljivih skupinah učencev in nudenje pomoči še posebej potrebno že v času osnovne šole.

Baydik in Bakkaloglu (2009) ugotavljata, da so učenci s posebnimi potrebami s strani vrstnikov manj sprejeti in bolj zavrnjeni kot njihovi vrstniki brez posebnih potreb; pri tem najpomembnejši dejavnik socialnega zavračanja predstavljajo vedenjske težave učencev $\mathrm{s}$ posebnimi potrebami. Po izsledkih več raziskav imajo učenci z učnimi težavami manj recipročnih prijateljstev, manj kvalitetna prijateljstva ter nižjo socialno sprejetost (Wiener in Schneider, 2002; Wiener in Tardif, 2004). Prav sprejetost $\mathrm{s}$ strani vrstnikov pa je pomemben dejavnik kasnejše psihosocialne prilagojenosti v otroštvu in odraslosti (Bagwell, Newcomb in Bukowski, 1998; Ladd in Troop-Gordon, 2003). Podobno tudi Kuhne in Wiener (2000) ugotavljata, da imajo učenci z učnimi težavami nižjo socialno preferenčnost in $\mathrm{v}$ razredu bolj verjetno zavzamejo zavrnjeni socialni položaj. Podobno
Stone in LaGreca (1990) ugotavljata, da so učenci z učnimi težavami glede na dobljene pozitivne in negativne izbire s strani sošolcev v večji meri umeščeni v skupini zavrnjenih in prezrtih učencev in v manjši meri v skupini priljubljenih in povprečnih $\mathrm{v}$ primerjavi $\mathrm{z}$ učenci, ki učnih težav nimajo. Iz rezultatov iste raziskave lahko razberemo še, da so ti učenci $\mathrm{v}$ enaki meri prisotni $\mathrm{v}$ skupini zavrnjenih in prezrtih učencev in tako tvorijo dve različni skupini učencev z učnimi težavami, ki pa se po svojih lastnostih precej razlikujeta, predvsem $\mathrm{v}$ vedenjskih značilnostih, stopnji tveganja in posledično optimalnih intervencijskih strategijah. Tudi raziskava na vzorcu 121 slovenskih četrtošolcev v šolskem letu 1995/96 je z uporabo vprašalnika o socialni integraciji pokazala, da so učenci z učnimi težavami v heterogenem razredu redne osnovne šole bistveno slabše integrirani kot njihovi sošolci, njihova neustrezna socialna vključenost pa je pogojena z značilnostmi, kot so slab šolski uspeh, socialne in interakcijske težave $\mathrm{v}$ odnosu do sošolcev in učiteljev, slaba samopodoba (Schmidt, 2001).

Manjšina raziskav zgoraj navedenih ugotovitev ne potrjuje; po pregledu več raziskav Dudley-Marling in Edmiaston (1985) ugotavljata, da se nekateri učenci z učnimi težavami umeščajo tudi v skupino priljubljenih učencev. Avtorici na podlagi tega pregleda zaključujeta, da prisotnost učnih težav ne pomeni nujno tudi slabše socialne sprejetosti, temveč predstavlja dejavnik tveganja za socialno zavračanje. Med učenci z učnimi težavami in učenci brez teh težav se tako lahko oblikujejo prijateljski odnosi, vendar pa učenci $z$ učnimi težavami ta diadna prijateljstva ocenjujejo kot bolj kakovostna $\mathrm{v}$ primerjavi z učenci brez učnih težav (Wiener in Schneider, 2002). Tako kljub pogostim poročilom in ugotovitvam, da so otroci z učnimi težavami manj sprejeti v primerjavi s svojimi vrstniki v inkluzivnih razredih, ta poročila v veliki meri zanemarjajo dejstvo, da imajo mnogi izmed njih vsaj enega prijatelja v razredu. Tako imajo iz kvantitativnega vidika sicer manj prijateljev in pripadajo ožji socialni mreži otrok s podobnimi učnimi in socialnimi značilnostmi, so pa ta prijateljstva s kvalitativnega vidika zelo pomembna za njihovo socialno prilagojenost (Juvonen in Bear, 1992). Tudi Wiener, Harris in Shirer (1990) ugotavljajo, da niso vsi otroci z učnimi težavami tudi zavrnjeni; rezultati njihove raziskave namreč kažejo, da se polovica učencev z učnimi težavami umešča $\mathrm{v}$ skupino učencev $\mathrm{S}$ povprečnim sociometričnim položajem. Juvonen in Bear (1992) poročata, da sta imeli dve tretjini otrok z učnimi težavami vsaj en vzajemen prijateljski odnos in več kot polovica jih je oblikovala prijateljski odnos s sošolcem brez učnih težav. Ista raziskava kaže tudi, da so otroci z učnimi težavami, še posebno fantje, dobro socialno integrirani, kar pomeni, da so sprejeti s strani sošolcev, imajo prijatelje in se tudi zaznavajo kot socialno sprejete (Juvonen in Bear, 1992). Nasprotno pa so dekleta $\mathrm{z}$ učnimi težavami dobila največ negativnih imenovanj in so bila najmanj zaželena (Conderman, 1995; Juvonen in Bear, 1992). Podoben trend ugotavljata tudi Stone in La 
Greca (1990), vendar se v njuni raziskavi razlike med dekleti in fanti niso izkazale kot statistično pomembne. Raziskovalci so ugotovili tudi, da je socialni položaj deklet $\mathrm{z}$ učnimi težavami bolj povezan $\mathrm{z}$ učnim uspehom kot pri fantih, ne glede na to, ali obiskujejo redno šolo ali šolo s prilagojenim programom (Bakker, Denessen, Bosman, Krijger in Bouts, 2007).

\section{Socialna sprejetost identificiranih nadarjenih učencev}

Pregled literature socialne sprejetosti nadarjeni otrok v šolskem okolju v splošnem kaže, da so nadarjeni učenci $\mathrm{v}$ razredu običajno dobro sprejeti s strani vrstnikov in zavzemajo ugoden sociometričen položaj. Skladno s teorijo selekcije in homofilije, ki trdi, da so si posamezniki znotraj vrstniške skupine podobni v različnih značilnostih (npr. učna uspešnost, čas, ki ga porabijo za domače naloge, uporaba substanc, pogostost zmenkov), nadarjeni učenci bolj verjetno sklepajo prijateljstva $\mathrm{z}$ enako nadarjenimi učenci V primerjavi $\mathrm{Z}$ nenadarjenimi (Peairs, 2011). Po analizi vedenjskih vzorcev kažejo nadarjeni učenci podobne vedenjske značilnosti kot otroci s priljubljenim sociometričnim položajem in jim drugi učenci pripisujejo bolj pozitivne in prosocialne značilnosti (Estell idr., 2009). Raziskave ugotavljajo, da so učno nadarjeni učenci bolj priljubljeni in manj zavrnjeni $\mathrm{v}$ primerjavi $\mathrm{z}$ njihovimi nenadarjenimi vrstniki (Cohen, Duncan in Cohen, 1994; Gallagher, 1958; Peairs, 2011). Do podobnih zaključkov so prišli tudi Wiener, Harris in Shirer (1990), ki ugotavljajo, da inteligentnost in učni dosežki statistično pomembno korelirajo s socialno sprejetostjo učencev. Zelo visoka inteligentnost pa ne pomeni nujno tudi boljše sprejetosti s strani vrstnikov, zato odnos med inteligentnostjo in socialno sprejetostjo bolje ponazarja obrnjena U krivulja. Raziskave, ki so primerjale socialno prilagojenost zmerno nadarjenih učencev in učencev $\mathrm{z}$ ekstremno visokimi intelektualnimi sposobnostmi, zaključujejo, da socialna sprejetost predstavlja večji problem učencem, ki imajo izjemno visoke intelektualne sposobnosti. Gross (1993; v Rimm, 2002) tako ugotavlja, da 80 \% učencev, ki imajo vrednost inteligenčnega kvocienta nad 160 , poroča o izkušnjah intenzivne socialne izolacije $\mathrm{v}$ programih splošnega izobraževanja in nenehno nadzoruje svoje socialno obnašanje $\mathrm{v}$ smeri prilagajanja pričakovanjem svoje skupine. Zelo nadarjeni učenci se zaznavajo kot manj priljubljene, vendar pa v primerjavi z ostalimi učenci ni razlik v samospoštovanju, depresivnosti ali pojavljanju disciplinskih problemov (Brody in Persson Benbow, 1986). Izjemno učno nadarjeni učenci zaradi svojih visokih učnih dosežkov večkrat tudi preskočijo razred (učna akceleracija), vendar so običajno manj sprejeti s strani vrstnikov in jih sošolci zaznavajo kot manj kooperativne, manj duhovite, manj pripravljene pomagati, manj vodje in manj družabne. Bolj negativno so bili ocenjeni fantje kot dekleta (Hoovegeen, van Hell in Verhoeven, 2009). Akcelerirani učenci pa so imeli v primerjavi z drugimi sošolci bolj pozitivno učno samopodobo, medtem ko so, še posebej pri akceleriranih fantih, beležili bolj negativno socialno samopodobo v primerjavi z ostalimi sošolci.

\section{Namen}

Namen pričujoče raziskave je ugotoviti, kakšen sociometrični položaj zavzemajo nadarjeni učenci in učenci z DSP oziroma kako sta omenjeni skupini učencev sprejeti s strani ostalih učencev v razredu. Dosedanje raziskave s tega področja dajejo nekonsistentne rezultate, poleg tega so bile $\mathrm{v}$ veliki večini opravljene $\mathrm{v}$ tujini in rezultate teh raziskav zaradi različnih kriterijev nadarjenosti in dodeljevanja dodatne strokovne pomoči težko posplošujemo na slovenski izobraževalni sistem, zato smo želeli preveriti stanje na slovenskem vzorcu osnovnošolcev.

$\mathrm{Na}$ podlagi izsledkov obstoječih raziskav tako domnevamo, da učenci $\mathrm{z}$ DSP (dodatno strokovno pomočjo) zavzemajo manj ugoden sociometrični položaj $\mathrm{v}$ primerjavi z ostalimi učenci oziroma so $\mathrm{v}$ postopku sociometrične klasifikacije v večji meri uvrščeni v skupini zavrnjenih in prezrtihučencev, medtem konadarjeniučenci zavzemajo ugodnejši sociometrični položaj v primerjavi z ostalimi učenci (priljubljeni učenci). Raziskave namreč pogosto ugotavljajo, da so učenci s posebnimi potrebami manj sprejeti in bolj zavrnjeni kot njihovi vrstniki brez posebnih potreb (Baydik in Bakkaloglu, 2009), medtem ko nadarjeni učenci običajno zavzemajo ugodnejše sociometrične položaje (Peairs, 2011). Ugotoviti želimo še, ali prihaja do razlik v sociometričnem položaju učencev z DSP glede na razred in spol. Domnevamo, da bodo učenci $z$ DSP bolje sprejeti v osmem razredu, predvsem zaradi razvoja socialne kognicije in večje sposobnosti zavzemanja perspektive drugega (Rutland idr., 2012). V skladu z ugotovitvami prejšnjih raziskav, ki ugotavljajo, da so učenke z DSP manj sprejete od fantov z DSP (Conderman, 1995; Juvonen in Bear, 1992; Stone in La Greca, 1990), domnevamo, da bodo dekleta z DSP manj sprejeta s strani vrstnikov kot fantje z DSP.

\section{Metoda}

\section{Udeleženci}

V raziskavo je bilo skupno vključenih 194 učencev iz 12 oddelkov priložnostno izbranih štirih osnovnih šol (50,5\% deklet). Od tega je 110 učencev obiskovalo šesti razred (44,5\% deklet) in 84 učencev osmi razred (58,3\% deklet).

V celotnem vzorcu je bilo 39 identificiranih nadarjenih učencev (30 učencev šestega razreda, 9 učencev osmega razreda, skupaj 20,1 \%) in 16 učencev, ki jim je nudena dodatna strokovna pomoč (11 učencev šestega razreda, 5 učencev osmega razreda, skupaj 8,2 \%), ter ena učenka osmega razreda, ki je identificirana kot nadarjena in hkrati prejema dodatno strokovno pomoč. 


\section{Pripomočki}

Sociometrična preizkušnja. Za pridobitev podatkov o sociometričnem položaju učencev je bila uporabljena sociometrična preizkušnja s pozitivnim (»Navedi tri sošolce, s katerimi se najraje družiš.») in negativnim kriterijem (»Navedi tri sošolce, s katerimi se najmanj rad/a družiš. $)$. Po t. i. pristopu standardiziranih dosežkov Coiea, Dodga in Coppotellija (1982), lahko na podlagi rezultatov sociometrične preizkušnje določimo mere socialne preferenčnosti oz. všečnosti (razlika med standardiziranimi pozitivnimi in negativnimi izbirami) in socialnega vpliva oz. opaznosti (vsota standardiziranih pozitivnih in negativnih izbir) učencev $\mathrm{v}$ skupini. Kombinacija obeh mer (všečnosti in opaznosti) omogoča razdelitev učencev v pet sociometričnih skupin (Jackson in Bracken, 1998):

- priljubljeni učenci z veliko pozitivnimi in malo ali nič negativnimi izbirami, značilna je visoka socialna preferenčnost;

- zavrnjeni učenci z veliko negativnimi in malo ali nič pozitivnimi izbirami, značilna je nizka socialna preferenčnost;

- prezrti učenci z malo ali nič dobljenimi izbirami, značilen je nizek socialni vpliv;

- kontroverzni učenci $\mathrm{z}$ veliko pozitivnimi in veliko negativnimi izbirami, značilen je visok socialni vpliv;

- povprečni učenci s povprečnim številom pozitivnih in negativnih izbir.

Število izbir je bilo omejeno na tri, pri negativnem kriteriju so lahko učenci izbrali tudi manj sošolcev.

\section{Postopek}

V vsakem izmed navedenih oddelkov je bila izvedena sociometrična preizkušnja s kriterijem skupno druženje. Podatki so bili zbrani v letu 2011 na štirih osnovnih šolah v pomurski regiji. Na dveh osnovnih šolah smo podatke zbirali sami, na dveh osnovnih šolah pa so podatke zbirale šolske svetovalne delavke, ki so dobile natančna navodila za izvedbo. Podatki so bili obdelani po prej omenjenem dvodimenzionalnem sociometričnem klasifikacijskem sistemu Coiea, Dodga in Coppotellija (1982). Informacije o tem, kateri učenci so nadarjeni oz. prejemajo dodatno strokovno pomoč, smo dobili od šolske svetovalne službe.

\section{Rezultati}

Za primerjavo povprečij števila pozitivnih, negativnih in vzajemnih izbir so učenci bili razdeljeni v tri skupine: identificirani nadarjeni učenci, nenadarjeni učenci z DSP ter nenadarjeni brez DSP; učenka, ki je identificirana nadarjena in ima hkrati nudeno DSP, je bila obravnavana posebej. Najprej smo analizirali število pozitivnih izbir, negativnih izbir in vzajemnih izbir posebej za skupino nadarjenih učencev, nenadarjenih učencev $\mathrm{z}$ DSP in nenadarjenih učencev brez DSP. Rezultati so prikazani v tabeli 1 .

Iz tabele 1 je razvidno, da so nadarjeni učenci $\mathrm{v}$ povprečju dobili največ pozitivnih in vzajemnih izbir ter najmanj negativnih; nasprotno so nenadarjeni učenci z DSP dobili najmanj pozitivnih in vzajemnih ter največ negativnih izbir, medtem ko so nenadarjeni učenci brez DSP na vseh omenjenih merah bili v povprečju celotnega vzorca.

Za preverjanje statistično pomembnih razlik v kazalcih socialne sprejetosti (pozitivne, negativne, vzajemne izbire) med omenjenimi skupinami je bila uporabljena enosmerna analiza variance. Število pozitivnih izbir se je med skupinami statistično pomembno razlikovalo, $F(2,192)=4,37, p<0,05, \omega^{2}=0,034$. Prav tako so se skupine statistično pomembno razlikovale po številu dobljenih negativnih izbir, $F(2,192)=7,98, p<0,01, \omega^{2}$ $=0,068$, medtem ko se skupine $\mathrm{v}$ številu vzajemnih izbir niso statistično pomembno razlikovale, $F(2,182)=0,71, p$ $=0,50, \omega^{2}=0,00$. Post hoc analize so zaradi neenakosti vzorcev skupin bile opravljene s Hochbergovim GT2 testom, ki je pokazal, da je povprečje števila pozitivnih izbir statistično pomembno višje pri nadarjenih učencih $\mathrm{v}$

Tabela 1. Mere opisne statistike za število pozitivnih, negativnih in vzajemnih izbir za skupino nadarjenih učencev, nenadarjenih učencev z DSP in nenadarjenih učencev brez DSP in njim pripadajoče standardizirane (z) vrednosti

\begin{tabular}{|c|c|c|c|c|c|c|}
\hline & \multicolumn{2}{|c|}{$\begin{array}{l}\text { Nadarjeni } \\
(N=39)\end{array}$} & \multicolumn{2}{|c|}{$\begin{array}{c}\text { Nenadarjeni z DSP } \\
\quad(N=16)\end{array}$} & \multicolumn{2}{|c|}{$\begin{array}{c}\text { Nenadarjeni brez DSP } \\
\qquad(N=138)\end{array}$} \\
\hline & $M$ & $S D$ & $M$ & $S D$ & $M$ & $S D$ \\
\hline Pozitivne izbire & 3,44 & 2,32 & 1,94 & 1,29 & 2,78 & 1,64 \\
\hline$z$-vrednosti & 0,32 & 1,14 & $-0,56$ & 0,77 & $-0,02$ & 0,91 \\
\hline Negativne izbire & 1,36 & 1,68 & 4,00 & 2,85 & 1,68 & 2,43 \\
\hline$z$-vrednosti & $-0,17$ & 0,69 & 0,89 & 1,32 & $-0,06$ & 0,95 \\
\hline Vzajemne izbire & 1,79 & 1,02 & 1,44 & 1,03 & 1,69 & 0,98 \\
\hline$z$-vrednosti & 0,11 & 1,03 & $-0,25$ & 1,04 & 0,00 & 0,99 \\
\hline
\end{tabular}

Opombe. $z$-vrednosti so bile izračunane glede na povprečno število in standardno deviacijo pozitivnih, negativnih in vzajemnih izbir znotraj posameznih razredov. 
Tabela 2. Sociometrični status nadarjenih učencev, nenadarjenih učencev z DSP in nenadarjenih brez DSP

\begin{tabular}{|c|c|c|c|c|c|c|c|c|c|c|}
\hline & \multicolumn{2}{|c|}{ Priljubljeni } & \multicolumn{2}{|c|}{ Zavrnjeni } & \multicolumn{2}{|c|}{ Prezrti } & \multicolumn{2}{|c|}{ Kontroverzni } & \multicolumn{2}{|c|}{ Povprečni } \\
\hline & $N$ & $\%$ & $N$ & $\%$ & $N$ & $\%$ & $N$ & $\%$ & $N$ & $\%$ \\
\hline Nadarjeni & 12 & 30,8 & 4 & 10,3 & 4 & 10,3 & 2 & 5,1 & 17 & 43,6 \\
\hline Nenadarjeni z DSP & 2 & 12,5 & 7 & 43,8 & 2 & 12,5 & 0 & 0,0 & 5 & 31,3 \\
\hline Nenadarjeni brez DSP & 35 & 25,4 & 22 & 15,9 & 25 & 18,1 & 6 & 4,3 & 50 & 36,2 \\
\hline
\end{tabular}

primerjavi z nenadarjenimi učenci, ki jim je nudena DSP $(p=0,015, d=0,73)$. Povprečno število negativnih izbir je bilo statistično pomembno nižje pri skupini nadarjenih učencev v primerjavi s skupino nenadarjenih učencev $\mathrm{z}$ DSP ( $p=0,001, d=1,29$ ). Povprečno število negativnih izbir je bilo pomembno nižje tudi pri skupini nenadarjenih učencev brez DSP v primerjavi s skupino nenadarjenih učencev z DSP ( $p=0,001, d=0,94)$. Kot že omenjeno pri povprečnih številih vzajemnih izbir ni prišlo do statistično pomembnih razlik med skupinami.

\section{Sociometrični položaji nadarjenih učencev in učencev z DSP}

$\mathrm{Na}$ osnovi prejetega števila pozitivnih in negativnih sociometričnih izbir smo učence umestili $\mathrm{v}$ pet sociometričnih skupin. Pri tem smo uporabili klasifikacijski postopek Coiea, Dodgea in Coppotellija (1982). Postopek temelji na standardizaciji pozitivnih in negativnih sociometričnih izbir ter predstavlja eno izmed najpogosteje uporabljanih sociometričnih klasifikacij. Za opis postopka glej Pečjak in Košir (2008). Standardizacija pozitivnih in negativnih izbir je bila izvedena znotraj posameznih oddelkov.

Iz tabele 2 lahko razberemo, da so identificirani nadarjeni učenci zavzeli vse sociometrične položaje, največ pa jih je bilo v skupini povprečnih in priljubljenih. Tudi nenadarjeni učenci brez DSP so bili prisotni v vseh sociometričnih skupinah in podobno kot nadarjeni, so v največji meri zavzemali povprečni ali priljubljeni sociometrični položaj. Nenadarjeni učenci z DSP so bili prisotni v vseh skupinah, razen $\mathrm{v}$ skupini kontroverznih učencev, sicer pa jih je največ zavzelo zavrnjeni in povprečni sociometrični položaj.

Zaradi nezadostnega števila frekvenc $\mathrm{v}$ posameznih pogojih za preverjanje razlik $\mathrm{v}$ deležih nenadarjenih učencev $z$ in brez DSP ter nadarjenih in nenadarjenih za vseh pet sociometrični skupin nismo mogli uporabiti Pearsonovega hi-kvadrat preizkusa. Za zagotovitev zadostnega števila frekvenc sta bili združeni skupini povprečnih in priljubljenih (sprejeti) ter skupini zavrnjenih in prezrtih (nesprejeti). Učencev, ki so se umestili v skupino kontroverznih učencev, pri teh analizah nismo upoštevali, saj jih zaradi velikega števila pozitivnih in negativnih izbir ne moremo opredeliti kot sprejete oz. nesprejete. Deleži učencev v posameznih skupinah so prikazani v tabeli 3 .

Rezultati Pearsonovega hi-kvadrat preizkusa kažejo, da je bila statistično pomembna razlika v sprejetosti med deležem nadarjenih učencev ter nenadarjenih učencev $\mathrm{z}$ DSP $\left(\chi^{2}[1]=6,15, p<0,05, \varphi=0,18\right)$, medtem ko razlika med nadarjenimi in nenadarjenimi brez DSP ni bila statistično pomembna $\left(\chi^{2}[1]=2,57, p>0,05, \varphi=0,12\right)$, prav tako ni bilo statistično pomembne razlike $\mathrm{v}$ sprejetosti med nenadarjenimi učenci z DSP in nenadarjenimi brez $\operatorname{DSP}\left(\chi^{2}[1]=2,59, p>0,05 ; \varphi=0,12\right)$. Po analizi podatkov predpostavke, da nenadarjeni učenci z DSP zavzemajo nižji (zavrnjeni ali prezrti), nadarjeni učenci pa višji sociometrični položaj (priljubljeni) v primerjavi z ostalimi učenci, ne moremo potrditi.

\section{Razlike v socialni sprejetosti učencev z DSP glede na razred}

Nadalje nas je zanimalo, ali delež socialno sprejetih oz. nesprejetih učencev z DSP razlikuje glede na razred. Rezultati so pokazali, da je delež nesprejetih učencev $\mathrm{z}$ DSP v 8. razredu višji $(83,3 \%)$ v primerjavi $z$ deležem nesprejetih učencev z DSP v 6. razredu (45,5\%). Za preverjanje statistične pomembnosti razlik $\mathrm{v}$ deležu sprejetih učencev z DSP glede na razred je bil uporabljen Pearsonov hi-kvadrat, ki ni pokazal statistično pomembnih razlik $\left(\chi^{2}[1]=1,00, p>0,05, \varphi=0,25\right)$. Delež socialno sprejetih učencev brez DSP (nadarjenih in nenadarjenih) v 6 . razredu $(69 \%)$ je bil primerljiv $z$ deležem v 8 . razredu (65\%).

Pri primerjavi vrednosti povprečij števila pozitivnih in negativnih izbir glede na razred in prisotnost oz.

Tabela 3. Sprejeti (priljubljeni, povprečni) in nesprejeti (zavrnjeni, prezrti) učenci glede na prisotnost DSP in nadarjenosti

\begin{tabular}{|c|c|c|c|c|c|c|}
\hline & \multicolumn{2}{|c|}{ Nadarjeni } & \multicolumn{2}{|c|}{ Nenadarjeni z DSP } & \multicolumn{2}{|c|}{ Nenadarjeni brez DSP } \\
\hline & $N$ & $\%$ & $N$ & $\%$ & $N$ & $\%$ \\
\hline Sprejeti & 29 & 78 & 7 & 44 & 85 & 64 \\
\hline Nesprejeti & 8 & 22 & 9 & 56 & 47 & 36 \\
\hline
\end{tabular}

Opombe. Sprejeti = priljubljeni in povprečni; nesprejeti $=$ zavrnjeni in prezrti. 
Tabela 4. Opisne statistike in rezultati t-testa za testiranje razlik prejetih pozitivnih in negativnih izbir pri učencih z DSP glede na razred in spol

\begin{tabular}{|c|c|c|c|c|c|c|c|c|c|c|}
\hline & \multicolumn{5}{|c|}{ Pozitivne izbire } & \multicolumn{5}{|c|}{ Negativne izbire } \\
\hline & $M$ & $S D$ & $t$ & $p$ & $d$ & $M$ & $S D$ & $t$ & $p$ & $d$ \\
\hline $\begin{array}{l}\text { DSP 6.r. } \\
(n=11)\end{array}$ & 2,09 & 1,38 & 0,91 & 0,38 & 0,46 & 4,45 & 2,46 & 0,91 & 0,38 & 0,47 \\
\hline $\begin{array}{l}\text { DSP 8.r. } \\
(n=6)\end{array}$ & 1,50 & 1,05 & & & & 3,17 & 3,31 & & & \\
\hline $\begin{array}{l}\text { Fantje z DSP } \\
(n=10)\end{array}$ & 1,80 & 1,40 & $-0,31$ & 0,76 & 0,16 & 4,10 & 3,14 & 0,17 & 0,87 & 0,09 \\
\hline $\begin{array}{l}\text { Dekleta z DSP } \\
(n=7)\end{array}$ & 2,00 & 1,16 & & & & 3,86 & 2,34 & & & \\
\hline
\end{tabular}

Opomba. $d=$ Cohenov $d$

odsotnost DSP opazimo manjše razlike med razredoma. V šestem razredu so učenci z DSP v povprečju dobili več pozitivnih izbir v primerjavi $\mathrm{z}$ učenci $\mathrm{z}$ DSP iz osmega razreda; ta razlika ni bila statistično pomembna. Po drugi strani pa so učenci z DSP v šestem razredu prejeli tudi več negativnih izbir $\mathrm{v}$ primerjavi $\mathrm{z}$ učenci osmega razreda. Tudi ta razlika ni bila statistično pomembna. Na podlagi teh rezultatov lahko zaključimo, da so učenci z DSP v 8. razredu niso bolj sprejeti v primerjavi s šestim razredom, rezultati nakazujejo celo nasproten trend, da so učenci $\mathrm{z}$ DSP v 8. razredu manj sprejeti, vendar razlike niso bile statistično pomembne.

\section{Socialna sprejetost deklet in fantov z DSP}

Fantje z DSP so v povprečju dobili manj pozitivnih izbir $\mathrm{v}$ primerjavi $\mathrm{z}$ dekleti $\mathrm{z}$ DSP. Ta razlika ni bila statistično pomembna (Tabela 4). Obenem so fantje z DSP dobili več negativnih imenovanj $\mathrm{v}$ primerjavi $\mathrm{z}$ dekleti z DSP; razlika ni bila statistično pomembna. Prav tako so dobili manj vzajemnih izbir $(M=1,30, S D=1,16) \mathrm{v}$ primerjavi z dekleti z DSP $(M=1,57, S D=0,79)$. Tudi ta razlika ni bila statistično pomembna $(t[15]=-0,536, p>$ $0,05, d=0,31)$.

Statistično pomembne razlike so se pokazale pri številu dobljenih negativnih izbir fantov $\mathrm{z}$ DSP v primerjavi s fanti brez DSP $(M=1,23, S D=1,75$; $t$ [94] $=2,84, p<0,05, d=1,51)$; medtem ko pri negativnih izbirah deklet glede na prisotnost DSP $(M=1,97, S D=$ $2,65)$ ni bilo statistično pomembnih razlik $(t[96]=1,83, p$ $>0,05, d=0,72)$; prav tako ni bilo statistično pomembnih razlik pri pozitivnih in vzajemnih izbirah. Predpostavko, da so dekleta z DSP v primerjavi s fanti z DSP slabše socialno sprejeta $\mathrm{v}$ skupini, lahko na podlagi dobljenih podatkov zavrnemo. Med navedenima skupinama sicer ni bilo statistično pomembnih razlik, rezultati pa kažejo, da so fantje nekoliko manj sprejeti, kar so pokazale tudi primerjave števila negativnih izbir.

\section{Razprava}

\section{Socialna sprejetost učencev z DSP}

Rezultati pričujoče raziskave skladno s predvidevanji kažejo, da so med tremi obravnavanimi skupinami - nadarjeni učenci, nenadarjeni učenci brez DSP in nenadarjeni učenci $\mathrm{z}$ DSP, v povprečju dobili najmanj pozitivnih in vzajemnih ter največ negativnih izbir prav slednji. Nenadarjeni učenci z DSP so dobili pomembno manj pozitivnih izbir $v$ primerjavi $z$ nadarjenimi učenci in več negativnih izbir v primerjavi z nadarjenimi učenci in nenadarjenimi učenci brez DSP; pri številu vzajemnih izbir se obravnavane skupine niso pomembno razlikovale.

Dobljeni rezultati delno sovpadajo $\mathrm{z}$ ugotovitvami prejšnjih raziskav, ki potrjujejo, da imajo učenci z učnimi težavami nižjo socialno preferenčnost (Kuhne in Wiener, 2000). Zanimiv je tudi podatek, da se nenadarjeni učenci z DSP v številu dobljenih pozitivnih izbir ne razlikujejo pomembno od nenadarjenih učencev brez DSP, medtem ko se pri primerjanju števila dobljenih negativnih izbir skupini razlikujeta. To pomeni, da so ti učenci pogosteje med tistimi, s katerimi se ostali učenci ne družijo radi; hkrati pa ta podatek kaže tudi na pomembnost uporabe dvodimenzionalnega klasifikacijskega sistema, saj z diferenciacijo med socialno preferenčnostjo in socialnim vplivom daje bolj celosten in natančen vpogled v strukturo vrstniških odnosov (Newcomb, Bukowski in Pattee, 1993).

Skladno z rezultati naše raziskave tudi rezultati drugih raziskav kažejo, da se učenci z ali brez učnih težav ne razlikujejo v številu recipročnih oz. vzajemnih imenovanj (Hoyle in Serafica, 1988). Nasprotno pa rezultati nekaterih raziskav kažejo, da imajo učenci z učnimi težavami manj recipročnih prijateljstev $\mathrm{v}$ primerjavi s svojimi sošolci (Wiener in Schneider, 2002). Pri tem pa nekateri avtorji opozarjajo, da pri interpretaciji takšnih podatkov ne smemo spregledati dejstva, da imajo mnogi izmed njih vsaj enega prijatelja v razredu, kar je zelo pomembno za 
njihovo socialno prilagojenost (Juvonen in Bear, 1992). Tudi na našem vzorcu se je pokazalo, da ima kar $81 \%$ učencev z DSP vsaj eno vzajemno izbiro znotraj razreda, kar je pomemben kazalec obstoja prijateljskih odnosov in potrjuje, da ti učenci niso nujno socialno izolirani oziroma osamljeni v razredu.

Največ nenadarjenih učencev z DSP je bilo umeščenih v skupini zavrnjenih in povprečnih učencev, najmanj pa $\mathrm{v}$ skupine priljubljenih, prezrtih ali kontroverznih učencev. $\mathrm{V}$ primerjavi $\mathrm{s}$ skupino nadarjenih in nenadarjenih učencev brez DSP je bilo največ nenadarjenih učencev z DSP uvrščenih med nesprejete učencev (zavrnjeni ali prezrti), vendar se je pomembna razlika $\mathrm{v}$ sprejetosti pokazala le v primerjavi z nadarjenimi učenci, ne pa tudi z nenadarjenimi brez DSP.

Dobljeni rezultati se tako ne skladajo z večino raziskav s področja socialne sprejetosti otrok s posebnimi potrebami, ki ugotavljajo, da imajo ti učenci nižji sociometrični položaj v primerjavi z ostalimi v razredu (npr. Baydik in Bakkaloglu, 2009). Več kot polovica nenadarjenih učencev z DSP v našem vzorcu je bila sicer umeščena $v$ skupino nesprejetih, kar se delno sklada $z$ dosedanjimi raziskavami, ki so ugotovile, da imajo učenci z učnimi težavami relativno nizek socialni status (Dudley-Marling in Edmiaston, 1985; Wiener in Tardif, 2004) ter da so bolj verjetno umeščeni v skupino zavrnjenih učencev (Kuhne in Wiener, 2000). Nekaj manj kot polovica nenadarjenih učencev z DSP (44 \%) je bila uvrščena v skupino sprejetih učencev, kar dokazuje, da niso vsi nenadarjeni učenci $\mathrm{z}$ DSP zavrnjeni, še več, nekaj jih je bilo uvrščenih celo v skupino priljubljenih. Tudi Wiener idr. (1990) so na svojem vzorcu prišli do podobnih ugotovitev - polovica učencev $\mathrm{z}$ učnimi težavami se je umestila $\mathrm{v}$ skupino s povprečnim sociometričnim položajem. Zaključimo lahko, da sta se na našem vzorcu pokazali dve podskupini nenadarjenih učencev z DSP, ki sta enakovredno zastopani v dveh skupinah: sprejeti, ki imajo ugoden sociometrični položaj in nesprejeti, ki spadajo v skupino zavrnjenih oziroma prezrtih. Tudi rezultati raziskave Sabornie (1990; v Bender in Wall, 1994) nakazujejo, da obstaja podskupina učencev z učnimi težavami, ki niso socialno zavrnjeni, ampak so ocenjeni zelo podobno kot učenci brez primanjkljajev, kar pa je odvisno tudi od vrste posebnih potreb. Ena izmed možnih razlag je, da se $\mathrm{v}$ skupino nesprejetih učencev z DSP umeščajo učenci druge etnične pripadnosti (v vzorec so namreč bili vključeni tudi učenci Romi, vendar pa etnične pripadnosti nismo vključili v raziskavo kot posebne spremenljivke), ki so pogosto učenci z DSP ali pa so razlike povezane s specifično vrsto posebnih potreb, vendar so potrebne nadaljnje raziskave za ugotovitev značilnosti teh dveh skupin.

Čeprav so druge raziskave pokazale, da učenci $\mathrm{z}$ DSP lahko zavzemajo nižje sociometrične položaje $v$ primerjavi z ostalimi učenci, tega $\mathrm{v}$ pričujoči raziskavi ne moremo potrditi. Rezultati sicer nakazujejo, da so manj sprejeti od svojih vrstnikov, vendar razlike niso bile statistično pomembne.

\section{Socialna sprejetost nadarjenih učencev}

Nadarjeni učenci so $\mathrm{v}$ primerjavi z ostalimi učenci dobili največ pozitivnih in vzajemnih ter najmanj negativnih imenovanj svojih sošolcev. $\mathrm{V}$ primerjavi $\mathrm{z}$ nenadarjenimi učenci $\mathrm{z}$ DSP so dobili statistično pomembno več pozitivnih izbir, medtem ko v primerjavi s skupino nenadarjenih brez DSP, število pozitivnih imenovanj ni bilo pomembno višje. Prav tako so nadarjeni učenci dobili pomembno manj negativnih imenovanj $\mathrm{V}$ primerjavi z nenadarjenimi učenci z DSP.

Nadarjeni učenci so najpogosteje zavzeli povprečni in priljubljeni sociometrični položaj, manj pa zavrnjeni, prezrti ali kontroverzni. Skoraj $80 \%$ nadarjenih učencev se je tako umestilo v skupino sprejetih, kar je pomembno več v primerjavi z učenci z DSP, ne pa tudi v primerjavi z ostalimi učenci brez DSP. Niso pa vsi nadarjeni učenci bili tudi priljubljeni; nekaj več kot $20 \%$ se jih je tako umestilo med zavrnjene in prezrte učence, $5 \%$ pa med kontroverzne. V to skupino učencev morda spadajo tudi izredno nadarjeni učenci, za katere je ugotovljeno, da imajo več problemov s socialno integracijo v primerjavi s povprečno nadarjenimi učenci (Gross, 1993; v Rimm, 2002), vendar bi bilo za tovrstne zaključke potrebno podrobneje raziskati vzroke socialnega nesprejemanja nadarjenih učencev oziroma diferencirati tudi znotraj skupine nadarjenih učencev glede na stopnjo nadarjenosti.

Dobljeni rezultati tako le delno potrjujejo ugotovitve prejšnjih raziskav, ki so pokazale, da so nadarjeni učenci bolj priljubljeni kot njihovi nenadarjenimi vrstniki (Peairs, 2011), saj so bili bolj priljubljeni samo $\mathrm{V}$ primerjavi $\mathrm{z}$ nenadarjenimi učenci z DSP, ne pa tudi z ostalimi sošolci. To vodi do zaključka, da se skupini nadarjenih učencev in nenadarjenih učencev $\mathrm{z}$ DSP razlikujeta $\mathrm{v}$ nekaterih značilnostih, ki so povezane s socialno sprejetostjo, pri tem pa se pomembno ne razlikujeta od ostalih učencev $\mathrm{v}$ razredu.

\section{Razlike v socialni sprejetosti učencev z DSP glede na razred in spol}

Predvidevali smo, da bodo učenci z DSP v osmem razredu bolje socialno sprejeti od učencev z DSP v šestem razredu, predvsem zaradi razvoja socialno kognitivnih sposobnosti pri starejših otrocih in $\mathrm{s}$ tem povezane sposobnosti zavzemanja perspektive drugega (Rutland idr., 2012) ter sprejemanja posameznikov in oblik vedenja, ki kakorkoli izstopajo. Delež sprejetih učencev $\mathrm{z}$ DSP se $\mathrm{v}$ šestem in osmem razredu ni statistično pomembno razlikoval, rezultati pa so pokazali nasproten trend od pričakovanega - učenci z DSP v šestem razredu so bili nekoliko bolj sprejeti kot učenci z DSP v osmem razredu. Takšen rezultat je med drugim lahko posledica tudi relativno majhnega vzorca učencev z DSP ali pa je sprejetost pogojena $\mathrm{z}$ drugimi dejavniki socialne sprejetosti, ki jih v raziskavi nismo preverjali. 
Pri primerjavi socialne sprejetosti med fanti in dekleti z DSP ni bilo statistično pomembnih razlik $\mathrm{v}$ številu pozitivnih, negativnih ali vzajemnih izbir. Pomembne razlike so se pokazale pri številu negativnih izbir med fanti $z$ in brez DSP (nadarjeni in nenadarjeni), kjer so fantje z DSP imeli več negativnih izbir kot fantje brez DSP, medtem ko pri dekletih teh razlik ni bilo. Rezultati te raziskave nakazujejo, da so fantje z DSP nekoliko manj sprejeti v primerjavi s fanti brez DSP. Dobljeni rezultati se ne skladajo $z$ ugotovitvami prejšnjih raziskav, ki so pokazale, da so učenke z DSP manj sprejete od fantov $\mathrm{z}$ DSP (Conderman, 1995; Juvonen in Bear, 1992; Stone in La Greca, 1990), predvsem zaradi povezanosti socialnega položaja deklet $\mathrm{z}$ učnimi težavami z učnim uspehom (Bakker idr. 2007). Poleg tega pa velja splošen stereotip, da so dekleta bolj učno in socialno kompetentna od fantov, tako dekleta $\mathrm{z}$ učnimi težavami s slabšim učnim uspehom še bolj odstopajo od povprečja (Juvonen in Bear, 1992).

Na podlagi podatkov te raziskave in pregleda literature lahko sklenemo, da je socialna integracija otrok $\mathrm{s}$ posebnimi potrebami v programe splošnega izobraževanja pogoj za pospeševanje socialne integracije teh otrok med druge otroke brez primanjkljajev in lahko pripomore $\mathrm{k}$ manjši stigmatizaciji, vendar pa sama po sebi ni zadostna za optimizacijo socialno-emocionalnega razvoja teh učencev. Prejšnje raziskave s tega področja in delno tudi ta nakazujejo, da so učenci z določenimi primanjkljaji manj sprejeti in potrebujejo več spodbude in pomoči pri vključevanju v socialne mreže, pri čemer pa nekateri avtorji opozarjajo, da samo izboljševanje socialnih spretnosti avtomatično ne poveča tudi socialne sprejetosti (Bender in Wall, 1994). Tako se lahko npr. agresiven učenec $\mathrm{v}$ ustreznem treningu socialnih veščin morda nauči ustreznih prosocialnih vedenjskih vzorcev, vendar bo le-te težko uporabil v skupini, ki je od njega vajena agresivnega obnašanja in se v skladu s temi pričakovanji tudi vede, zato je potrebno celotno skupino pripraviti do tega, da sprejme takega učenca (Košir, 2005). Pri tem pa moramo upoštevati predpostavljene vzroke za nesprejetost vsakega posameznika ter v načrt intervencije vključiti vse udeležence: učenca, ki ima težave, njegove sošolce in učitelja (Pečjak in Košir, 2008). Pomembno vlogo pri tem igrajo skrbno izbrane aktivnosti skupinskega učenja, ki zagotavljajo, da se učenci z določenimi primanjkljaji ne grupirajo $\mathrm{v}$ eno skupino in da skupine sestavljajo učenci različnih sposobnosti (Wiener in Tardif, 2004).

Spregledati pa ne smemo nekaterih nadarjenih učencev, še posebej tistih $\mathrm{z}$ visokimi intelektualnimi sposobnostmi, ki poročajo o občutkih socialne izolacije. Te učence je potrebno spodbujati in jim nuditi podporo $\mathrm{v}$ smislu organiziranja poletnih taborov za nadarjene učence, debatnih krožkov ter intelektualnih in kreativnih skupin, kjer bodo ti učenci začeli ceniti svoj talent in oblikovali trdno samopodobo in identiteto (Rimm, 2002).

Rezultati te raziskave nakazujejo, da niso vsi učenci z DSP tudi zavrnjeni učenci, zaradi svojih primanjkljajev na določenem področju pa se vendarle umeščajo $\mathrm{v}$ skupino učencev $\mathrm{z}$ večjim tveganjem za socialno izolacijo. Učitelji, svetovalni delavci in drugi profili strokovnjakov, ki delajo s temi učenci, morajo biti pozorni na te učence in spremljati spremembe $\mathrm{v}$ njihovem socialnem vedenju ter pravočasno odreagirati in pripraviti načrt intervencije. Pomoč nesprejetim učencem, ne le učencem $\mathrm{z}$ učnimi primanjkljaji, je nujna, saj ima socialna nesprejetost $\mathrm{v}$ obdobju odraščanja pomembno vlogo pri nadaljnjem razvoju posameznika ter tudi pri socialnem prilagajanju v kasnejšem življenju.

$\mathrm{V}$ raziskavo so bili vključeni tako učenci z DSP kot identificirani nadarjeni učenci, ki prav tako sodijo $\mathrm{V}$ skupino učencev s posebnimi potrebami. Veliko raziskav (predvsem starejših) nadarjenih učencev ne obravnava kot učence s posebnimi potrebami, ki zahtevajo prilagajanje in posebne oblike dela, zato vključitev teh učencev $\mathrm{v}$ raziskovalni vzorec opredeljujemo kot prednost. Kot slabost oziroma omejitev raziskave lahko navedemo obravnavanje skupine učencev z DSP kot homogene, brez razlikovanja glede na vrsto primanjkljajev, zaradi katerih imajo nekateri učenci nudeno dodatno strokovno pomoč; prav tako $\mathrm{v}$ raziskavi ni opredeljeno, katera so področja nadarjenosti posameznih učencev. Morda imajo te razlike pomemben vpliv na socialno sprejetost, zatoje v nadaljnjem raziskovanju potrebno to natančneje opredeliti. Relativno majhno število učencev $\mathrm{z}$ DSP $\mathrm{v}$ vzorcu onemogoča posploševanje na celotno populacijo, daje pa splošno informacijo o sociometričnem položaju teh učencev. Majhen vzorec učencev z DSP je lahko tudi razlog, da se nekatere relativno velike razlike med skupinami učencev niso pokazale kot statistično pomembne. Prav tako velja omeniti, da bili podatki zbirani samo na šolah ene (pomurske) regije, zato rezultatov najverjetneje ni mogoče posplošiti na celotni slovenski prostor.

V nadaljnjih raziskavah bi bilo smiselno preučiti socialno sprejetost učencev $\mathrm{s}$ posebnimi potrebami $\mathrm{v}$ prilagojenem programu osnovne šole ter primerjati rezultate $\mathrm{z}$ učenci, ki so vključeni $\mathrm{v}$ programe rednega izobraževanja. Kot že omenjeno, bi lahko preučili še povezanost socialnoekonomskega statusa in etnične pripadnosti s socialno sprejetostjo. Zanimivo bi bilo preveriti še učinek različnih skupinskih aktivnosti na spremembe v socialni sprejetosti.

\section{Literatura}

Bagwell, C. L., Newcomb, A. F. in Bukowski, W. M. (1998). Preadolescent friendship and peer rejection as predictors of adult adjustment. Child Development, 69, 140-153.

Bain, S. K. in Bell, S. M. (2004). Social self-concept, social attributions, and peer relationships in fourth, fifth, and sixth graders who are gifted compared to high achievers. Gifted Child Quarterly, 48, 167-178.

Bakker, J. T. A., Denessen, E., Bosman, A. M. T., Krijger, E. in Bouts, L. (2007). Sociometric status and selfimage of children with specific and general learning disabilities in Dutch general and special education classes. Learning Disability Quarterly, 30, 47-62. 
Baydik, B. in Bakkaloglu, H. (2009). Predictors of sociometric status for low socioeconomic status elementary mainstreamed students with and without special needs. Educational Science: Theory and Practice, 9, 435-447.

Bender, W. N. in Wall, M. E. (1994). Social-emotional development of students with learning disabilities. Learning Disability Quarterly, 17, 323-341.

Brody, L. E. in Persson Benbow, C. (1986). Social and emotional adjustment of adolescents extremely talented in verbal or mathematical reasoning. Journal of Youth and Adolescence, 15, 1-18.

Buhs, E. S. in Ladd, G. W. (2001). Peer rejection as an antecedent of young children's school adjustment: An examination of mediating processes. Developmental Psychology, 37, 550-560.

Cohen, R., Duncan, M. in Cohen, S. L. (1994). Classroom peer relations of children participating in a pull-out enrichment program. Gifted Child Quarterly, 38, 33-37.

Coie, J. D., Dodge, K. A. in Coppotelli, H. A. (1982). Dimensions and types of social status: A crossage perspective. Developmental Psychology, 18, 557-570.

Conderman, G. (1995). Social status of sixth- and seventhgrade students with learning disabilities. Learning Disability Quarterly, 18, 13-24.

Dudley-Marling, C. C. in Edmiaston, R. (1985). Social status of learning disabled children and adolescents: A review. Learning Disability Quarterly, 8, 189-204.

Estell, D. B., Farmer, T. W., Irvin, M. J., Crowther, A., Akos, P. in Boudah, D. J. (2009). Students with exceptionalities and the peer group context of bullying and victimization in late elementary school. Journal of Child and Family Studies, 18, 136-150.

Gadeyne, E., Ghesquière, P. in Onghena, P. (2004). Psychosocial functioning of young children with learning problems. Journal of Child Psychology in Psychiatry, 45, 510-521.

Gallagher, J. J. (1958). Peer acceptance of highly gifted children in elementary schools. The Elementary School Journal, 58, 465-470.

Gifford-Smith, M. E. in Brownell, C. A. (2003). Childhood peer relationships: Social acceptance, friendship, and peer networks. Journal of School Psychology, 41, 235-284.

Guralnick, M. J. (1999). The nature and meaning of social integration for young children with mild developmental delays in inclusive settings. Journal of Early Intervention, 22, 70-86.

Hoovegeen, L., van Hell, J. G. in Verhoeven, L. (2009). Self-concept and social status of accelerated and nonaccelerated students in the first 2 years of secondary school in the Netherlands. Gifted Child Quarterly, 53, 50-67.

Hoyle, S. G. in Serafica, F. C. (1988). Peer status of children with and without learning disabilities: A multimethod study. Learning Disability Quarterly, 11, 322-332.
Jackson, L. D. in Bracken, B. A. (1998). Relationship between students' social status and global and domain-specific self-concepts. Journal of School Psychology, 36, 233-246.

Jeriček, H. (2003). Nadarjenost - privilegij ali breme? V M. Blažič (ur.), Nadarjeni med teorijo in prakso - zbornik prispevkov (str. 92-100). Novo Mesto: Slovensko združenje za nadarjene Novo Mesto.

Juvonen, J. in Bear, G. (1992). Social adjustment of children with and without learning disabilities in integrated classrooms. Journal of Educational Psychology, 84, 322-300.

Kalambouka, A., Farrell, P., Dyson, A. in Kaplan, I. (2007). The impact of placing pupils with special needs in mainstream schools on the achievement of their peers. Educational Research, 49, 365-382.

Kobal Grum, D., Kobal, B., Celeste, M., Dremelj, P., Smolej, S. in Nagode, M. (2009). Sociopsihološki vidiki izobraževanja oseb s posebnimi potrebami (znanstveno poročilo). Ljubljana: Pedagoški inštitut.

Košir, K. (2005). Zavrnjeni učenci: Kako jim pomagati in zakaj je to potrebno? Vzgoja in izobraževanje, 36, $43-46$.

Kuhne, M. in Wiener, J. (2000). Stability of social status of children with and without learning disabilities. Learning Disabilities Quarterly, 23, 64-75.

Ladd, G. W. in Troop-Gordon, W. (2003). The role of chronic peer difficulties in the development of children's psychological adjustment problems. Child development, 74, 1344-1367.

Litster, K. in Roberts, J. (2011). The self-concepts and perceived competencies of gifted and non-gifted students: A meta-analysis. Journal of Research in Special Educational Needs, 11, 130-140.

Newcomb, A. F., Bukowski, W. M. in Pattee, L. (1993). Children's peer relations: A meta-analytic review of popular, rejected, neglected, controversial, and average sociometric status. Psychological Bulletin, $113,99-128$.

Opara, B. (2005). Otroci s posebnimi potrebami v vrtcih in šolah: Vloga in naloga vrtcev in šol pri vzgoji in izobraževanju otrok $s$ posebnimi potrebami. Ljubljana: Centerkontura.

Opara, B., Barle Lakota, A., Globačnik, B., Kobal Grum, D., Košir, S., Macedoni Lukšič, M., Zorc, D., Bregar Golobič, K., Molan, N, Vovk Ornik, N. in Klavžar, K. (2010). Analiza vzgoje in izobraževanja otroks posebnimi potrebami $v$ Sloveniji. Ljubljana: JZR Pedagoški inštitut.

Peairs, K. F. (2011). The social world of gifted adolescents: Sociometric status, friendship and social network centrality (neobjavljena doktorska disertacija). Duke University, Durham.

Pečjak, S. in Košir, K. (2008). Poglavja iz pedagoške psihologije: Izbrane teme. Ljubljana: Oddelek za psihologijo Filozofske fakultete. 
Renzulli, J.S. (1986). The three-ring conception of giftedness: A developmental model for creative productivity. In R. J. Sternberg \& J. E. Davidson (ur.), Conceptions of giftedness (pp. 53-92). Cambridge: Cambridge University Press.

Rimm, S. (2002). Peer pressures and social acceptance of gifted children. V M. Neihart, S. M. Reis, N. M. Robinson in S. M. Moon (ur.), The social and emotional development of gifted children: What do we know? (str. 13-19). Washington, ZDA: The National Association for Gifted Children.

Rutland, A., Cameron, L., Jugert, P., Nigbur, D., Brown, R., Watters, ... Le Touze, D. (2012). Group identity and peer relations: A longitudinal study of group identity, perceived peer acceptance, and friendships amongst ethnic minority English children. British Journal of Developmental Psychology, 30, 283-302.

Schmidt, M. (2001). Socialna integracija otrok s posebnimi potrebami $v$ osnovno šolo. Maribor: Pedagoška fakulteta Maribor.

Stone, W. L. in La Greca, A. M. (1990). The social status of children with learning disabilities: A reexamination. Journal of Learning Disabilities, 23, 32-37.

Subotnik, R. F., Olszewski-Kubilius, P. in Worrell, F. C. (2011). Rethinking giftedness and gifted education: A proposed direction forward based on psychological science. Psychological Science in the Public Interest, $12,3-54$.

Travers, J. F., Elliott, S. N. in Kratochwill, T. R. (1993). Educational psychology: Effective teaching, effective learning. Madison: Brown \& Benchmark.

Wiener, J., Harris, P. J. in Shirer, C. (1990). Achievement and social-behavioral correlates of peer status in LD children. Learning Disability Quarterly, 13, 114-127.

Wiener, J. in Schneider, B. H. (2002). A multisource exploration of the friendship patterns of children with and without learning disabilities. Journal of Abnormal Child Psychology, 30, 127-141.

Wiener, J. in Tardif, C. Y. (2004). Social and emotional functioning of children with learning disabilities: Does special education placement make a difference? Learning Disabilities Research \& Practice, 19, 20-32.

Zakon o usmerjanju otrok k posebnimi potrebami (2006). Uradni list RS, 118/2006. Pridobljeno s spletne strani http://www.zrss.si/pdf/050911092746_upp_zakon_ url_03_2007_zuopp-upbl.pdf, dne 14.7.2013. 